\title{
PERAN PASAR LELANG DALAM PEMASARAN CABAI DI KELOMPOK TANI LAHAN PASIR PANTAI KULON PROGO, YOGYAKARTA
}

\author{
Eksa Rusdiyana* \\ Program Studi Penyuluhan dan Komunikasi Pertanian, Fakultas Pertanian, Universitas Sebelas Maret \\ ${ }^{*}$ Corresponding author: eksarusdiyana@staff.uns.ac.id
}

\begin{abstract}
This study aims to analyze the role of auction market institutions in marketing the chili by sand land farmer community in Kulon Progo Regency, Yogyakarta. This study was a quantitative study using questioner, interviews, and observations to collect the data. The results showed that the auction market institutions formed sand land farmer community had the effective roles in the marketing of chili including the exchange function, physical function, and the provision of infrastructure function. The existence of the auction market was able to increase the bargaining position of farmers to middlemen traders through the sale of the auction system. The concept of exchange theory in the marketing system of chili gave rewards toward the increasing of chili selling price and provided service marketing which made the work of farmers more effective. In addition, the auction market system gave sacrifices to farmers in the form of non-cash payments, but the auction market managers provided certainty of payment. The comparison between rewarded with the sacrifice still gave more value to the farmer's profit, it made the farmers repeating the marketing of chili through auction markets.
\end{abstract}

Keywords: Auction market; Chili; Kulon Progo; Marketing

Cite this as: Rusdiyana, E. 2017. Peran Pasar Lelang dalam Pemasaran Cabai di Kelompok Tani Lahan Pasir Pantai Kulon Progo, Yogyakarta. Caraka Tani: Journal of Sustainable Agriculture. 32(1), 1-8. doi: http://dx.doi.org/10.20961/carakatani.v32i1.14666

\section{PENDAHULUAN}

Petani seringkali menghadapi tekanan harga saat menjual hasil panennya secara personal. Perlakuan seperti ini pernah dialami oleh kelompok tani cabai lahan pasir pantai di Kabupaten Kulon Progo yang memasarkan cabainya secara langsung melalui pedagang pengepul. Pengalaman memperoleh tekanan harga membuat petani berinisiatif membentuk pasar lelang sebagai sarana untuk memasarkan cabainya secara berkelompok. Keberadaan pasar lelang terbukti memberikan keuntungan harga jual yang lebih tinggi bagi petani. Berdasarakan penelitian Kuntadi (2011) perolehan selisih harga cabai yang dijual di pasar lelang mencapai 61 juta/hektar/musim jika dibandingkan dengan di luar pasar lelang (pengepul). Sayangnya, keunggulan tersebut belum membuat petani mempercayakan $100 \%$ cabainya untuk dijual di pasar lelang, dikarenakan sistem pembayaran yang tidak cash. Peran pasar lelang pada aspek fungsi penyediaan sarana tersebut dinilai dominan sebagai peran yang paling lemah dalam memfasilitasi pemasaran cabai petani.

Pasar lelang merupakan hasil pengembangan kelompok tani menjadi lembaga/unit pemasaran yang berfungsi sebagai sarana pemasaran secara kolektif bagi para petani lahan pasir pantai di Kulon Progo. Secara umum kelompok tani di Indonesia masih sedikit kelompok tani yang mampu bertransformasi dari bentuk kolektifitas kegiatan onfarm ke kegiatan off farm (pemasaran dan pengolahan hasil pertanian). Sehingga keberadaan pasar lelang menjadi salah satu contoh yang diharapkan bisa diduplikasi oleh kelompok tani lain yang ada di Indonesia dalam rangka memperkuat posisi tawar petani. Berdasarkan latar belakang tersebut, penelitian ini bertujuan untuk menilai peran lembaga pasar lelang dalam memfasilitasi fungsi pemasaran cabai petani secara kolektif di Kabupaten Kulon Progo.

\section{METODE PENELITIAN}

Metode dasar yang digunakan dalam studi ini adalah metode deskriptif dengan pendekatan 
kuantitatif. Pemilihan lokasi diambil secara sengaja berdasarkan pertimbangan keberadaan pasar lelang yang digunakan petani untuk memasarkan cabainya yaitu di Kecamatan Panjatan, Kulon Progo. Responden penelitian berjumlah 85 orang petani yang dipilih secara proporsional random sampling dari kelompok lelang di Desa Bugel, Pleret dan Garongan. Data hasil penelitian dianalisis dengan menggunakan model interaktif.

\section{HASIL DAN PEMBAHASAN}

\section{Pasar Lelang sebagai Pilihan Utama Petani dalam Memasarkan Cabai}

Pusat Penyuluhan Pertanian, Badan Penyuluhan dan Pengembangan SDM Pertanian, Kementerian Pertanian (2012) menilai bahwa kelompok tani perlu dikembangkan menjadi lembaga ekonomi petani baik yang berwujud koperasi, perseroan, maupun lembaga pemasaran seperti pasar lelang. Mardjoko (2012) mengartikan pasar lelang sebagai suatu pasar dimana penjual (petani sebagai produsen) menawarkan komoditi (hasil panennya) dengan volume, mutu, harga tertentu dan berinteraksi dengan pembeli melalui harga penawaran tertinggi dan pembayarannya dilakukan secara tunai. Sebagai suatu bentuk saluran pemasaran, efektifitas pasar lelang dalam menjalankan fungsi pemasaran akan menentukan apakah petani akan menggunakan saluran tersebut atau tidak atau justru petani akan menjalankan fungsi pemasaran itu sendiri. Mulyadi (2011) menyebutkan jika fungsi pemasaran lebih efektif dilakukan oleh pasar lelang maka petani akan mempercayakan pemasaran cabainya melalui pasar lelang.

Petani yang menjual cabainya secara langsung kepada tengkulak memiliki kewajiban menjalankan fungsi pemasaran sendiri. Petani akan menyiapkan segala sesuatunya mulai pengangkutan dari lahan, grading, sortasi, penimbangan, serta melakukan pengemasan secara mandiri. Hal tersebut menyebabkan petani mengeluarkan biaya dan tenaga yang tidak sedikit. Apabila fungsi tersebut tidak dilaksanakan oleh petani (diserahkan kepada pedagang pengepul) maka konsekuensinya petani akan memperoleh pengurangan harga jual. Akibatnya, pada posisi ini petani akan memperoleh harga yang lebih rendah, bahkan seringkali petani memperoleh tekanan harga beli dari pedagang pengepul. Tekanan harga yang lebih rendah ini juga turut disebabkan karena semakin panjangnya rantai pemasaran yang berakibat adanya pengurangan harga jual di setiap mata rantai penjualan. Sebaliknya, keberadaan pasar lelang memperpendek saluran pemasaran cabai yang ada dengan menghilangkan rantai pedagang pengepul. Adanya satu mata rantai pemasaran yang hilang ini menyebabkan pemasaran cabai menjadi lebih efektif karena akan mengurangi margin pemasaran pada rantai pengepul sehingga petani akan memperoleh harga jual cabai yang lebih tinggi.

Interaksi yang terjadi antara petani, pengelola pasar lelang dan pedagang cabai merupakan bentuk interaksi sosial yang bermuatan ekonomi. Petani merupakan pihak produsen yang memiliki cabai, pedagang tengkulak merupakan pihak yang memerlukan cabai sedangkan pengelola pasar lelang merupakan pihak yang memfasilitasi pertemuan kebutuhan kedua pihak tersebut. Petani berkepentingan menjual cabainya sedangkan pedagang tengkulak berkepentingan membeli cabai tersebut. Pertemuan kebutuhan ini menimbulkan hubungan resiprosisten (interaksi saling memerlukan) diantara kedua belah pihak yaitu petani sebagai penyedia cabai serta pedagang tengkulak sebagai pencari cabai. Pada interaksi ini, petani maupun pedagang merupakan pihak yang membutuhkan pasar lelang. Transaksi ekonomi tersebut hanya akan terjadi dengan dua catatan, yaitu adanya jaringan informasi pasar serta adanya struktur komunikasi.

\section{Informasi Pasar}

Modal utama informasi pasar ada 2 hal, yaitu: (a) siapa pihak yang memiliki kebutuhan memperoleh atau mencari cabai dan (b) siapa yang berkepentingan menjual cabai. Pengelola pasar lelang mampu menangkap informasi pasar tersebut dan mempertemukan kedua kebutuhan itu melalui fasilitasi keberadaan pasar lelang.

2. Struktur komunikasi

Struktur komunikasi untuk menentukan kesepakatan harga berwujud ketersediaan barang (cabai). Hal ini diwakili oleh dua kondisi berikut; (a) apabila harga cabai tinggi maka petani sebagai pihak yang memiliki cabai berada pada struktur komunikasi yang lebih tinggi (dominan) dari pedagang tengkulak. Hal ini dikarenakan berapapun harga cabai dan pedagang tengkulak sangat memerlukannya, petani memiliki dominasi untuk menentukan harga jual (b) sedangkan apabila harga cabai 
rendah, dan petani berkepentingan untuk segera menjual cabainya, maka pedagang tengkulak selaku calon pembeli memiliki posisi yang dominan untuk menentukan harga beli cabai tersebut.

Keberadaan pasar lelang mampu menjembatani dominasi salah satu pihak atas pihak yang lainnya. Hal ini dikarenakan harga diputuskan berdasarkan mekanisme yang sesuai dengan hukum pasar persaingan sempurna; yaitu tidak dipengaruhi oleh penjual maupun pembeli. Peran pengelola pasar lelang yang mampu memberikan informasi pasar serta menyeimbangkan struktur komunikasi antara petani dengan pedagang, pada akhirnya memberikan 2 akibat, yaitu: (a) harga jual cabai di pasar lelang yang lebih tinggi dari pada harga jual ke pedagang pengepul, serta (b) adanya peran pengelola pasar lelang yang mempermudah kerja pemasaran yang dilakukan oleh petani.

Fungsi pemasaran juga akan lebih efektif dijalankan oleh pasar lelang dibandingkan dijalankan sendiri oleh petani. Dalam memilih saluran pemasaran berdasarkan prinsip yang disampaikan oleh Firdaus (2008) akan dinilai dari efektifitas kerja saluran pemasaran tersebut dalam menjalankan fungsi pemasaran (pengangkutan, pemasaran, mencari pembeli, menetapkan harga dan lain-lain). Apabila saluran pemasaran memberikan efektifitas kerja dengan biaya yang lebih murah maka akan cenderung dipilih petani dibanding dengan saluran pemasaran yang lain maupun dikerjakan sendiri oleh petani.

\section{Peran Pasar Lelang}

Peran pasar lelang dalam memfasilitasi fungsi pemasaran dikelompokkan menjadi 3 fungsi utama yaitu fungsi pertukaran, fungsi fisis, serta fungsi penyediaan sarana prasarana. Masingmasing peran pengelola pasar lelang atas ketiga fungsi utama tersebut dijabarkan sebagai berikut.

\section{Peran atas Fungsi Pertukaran}

Peran atas fungsi pertukaran pada intinya menyangkut aktifitas pengalihan hak kepemilikan dari satu pihak ke pihak lainnya. Fungsi ini terdiri atas beberapa fungsi turunan antara lain fungsi penjualan dan fungsi pembelian. Fungsi penjualan meliputi aktifitas dalam rangka menjual barang tersebut kepada pihak yang memerlukan. Sedangkan fungsi pembelian meliputi segala kegiatan dalam rangka memperoleh produk dari sumber produk dengan kualitas dan jumlah yang diinginkan pembeli. Fungsi pembelian dalam hal ini adalah peran yang dilakukan oleh pengelola pasar lelang dalam rangka memfasilitasi petani untuk menitipkan cabainya kepada pengelola pasar lelang agar dijualkan melalui sistem lelang.

Tabel 1. Tingkat Capaian Peran Pengelola Pasar Lelang atas Fungsi Pertukaran

\begin{tabular}{|c|c|c|c|c|}
\hline No. & Indikator & $\begin{array}{l}\text { Interval } \\
\text { Skor }\end{array}$ & $\begin{array}{l}\text { Capaian } \\
\text { Skor }\end{array}$ & $\begin{array}{c}\text { Tingkat } \\
\text { Capaian }(\%)\end{array}$ \\
\hline \multicolumn{5}{|c|}{ Fungsi Penjualan } \\
\hline 1. & Membuat aturan standar cabai yang dipasarkan di pasar lelang & $0-2$ & 1,4 & 70 \\
\hline 2. & Menjalin komunikasi dengan pembeli & $0-3$ & 2,15 & 72 \\
\hline 3. & Mempromosikan (menginfokan) cabai kepada calon pembeli & $0-3$ & 2,47 & 82 \\
\hline 4. & Menambah jumlah calon pembeli di pasar lelang & $0-2$ & 1,34 & 67 \\
\hline 5. & Memimpin jalannya proses lelang & $0-2$ & 1,38 & 69 \\
\hline 6. & Membuat perjanjian dengan pemenang lelang & $0-2$ & 1,44 & 72 \\
\hline 7. & Mengatur periode operasional pasar lelang selama panen cabai & $0-2$ & 1,39 & 70 \\
\hline 8. & Menentukan jadwal buka pasar lelang setiap minggunya & $0-2$ & 1,25 & 62 \\
\hline Jum & ah Peran atas Fungsi Penjualan & 18 & 12,82 & 71,22 \\
\hline \multicolumn{5}{|c|}{ Fungsi Pembelian } \\
\hline 9. & Memfasilitasi pengumpulan panen cabai petani di pasar lelang & $0-2$ & 1,47 & 73 \\
\hline 10. & Membuat kesepakatan dengan petani terhadap sistem penjualan & $0-3$ & 2,30 & 77 \\
\hline 11. & $\begin{array}{l}\text { Membuat kesepakatan dengan petani tentang sistem dan waktu } \\
\text { pembayaran }\end{array}$ & $0-3$ & 2,18 & 73 \\
\hline & Melakukan potongan harga cabai sesuai kesepakatan & $0-3$ & 2,62 & 87 \\
\hline \multicolumn{2}{|r|}{ Jumlah Peran atas Fungsi Pembelian } & 11 & 8,57 & 77,91 \\
\hline & Jumlah Keseluruhan & 29 & 21,39 & 73,76 \\
\hline
\end{tabular}

Sumber: Analisis data primer, 2014 
Berdasarkan Tabel 1, peran atas fungsi pertukaran mencapai $73,76 \%$, peran atas fungsi penjualan mencapai $71,22 \%$ sedangkan peran atas fungsi pembelian mencapai $77,91 \%$. Peran atas fungsi pembelian ini melibatkan interaksi langsung antara petani dengan pengelola pasar lelang. Apabila dikategorikan, capaian peran atas fungsi pertukaran yang dilakukan oleh pengelola pasar lelang tampak dalam Tabel 2 berikut.

Tabel 2. Distribusi Kategori Peran Pengelola Pasar Lelang atas Fungsi Pertukaran

\begin{tabular}{lccc}
\hline $\begin{array}{l}\text { Kategori } \\
\text { (skor) }\end{array}$ & $\begin{array}{c}\text { Jumlah } \\
\text { (orang) }\end{array}$ & $\begin{array}{c}\text { Persentase } \\
(\%)\end{array}$ \\
\hline Rendah & $0-9,67$ & 0 & 0 \\
Sedang & $9,68-19,33$ & 13 & 15,29 \\
Tinggi & $19,34-29$ & 72 & 84,71 \\
\hline \multicolumn{2}{r}{ Jumlah } & 85 & 100 \\
\hline
\end{tabular}

Sumber: Analisis data primer, 2014

Berdasarkan Tabel 2, 72 orang $(84,71 \%)$ petani menilai peran pasar lelang atas fungsi pertukaran pada kategori tinggi. Tingginya capaian pada fungsi pertukaran dikarenakan fungsi ini tidak bisa dilakukan oleh pihak lain (hanya bisa dilakukan oleh pengelola pasar lelang). Artinya selama petani menggunakan saluran pemasaran pasar lelang maka hanya pengelola pasar lelang yang bisa memenuhi peran atas fungsi pertukaran tersebut.

Perilaku petani untuk memasarkan cabainya di pasar lelang didasarkan prinsip bahwa pasar lelang lebih efektif menjalankan fungsi pemasaran atas fungsi pertukaran tersebut jika dibandingkan dengan dilakukan oleh petani sendiri. Petani sangat terbantu dalam memperoleh jaringan pedagang, pengumpulan cabai, perjanjian kesepakatan pembayaran serta fungsi komunikasi dengan pedagang. Petani tidak pelu lagi melakukan hal tersebut karena sudah mempercayakan semua pada pelayanan pasar lelang.

\section{Peran Pengelola Pasar Lelang atas Fungsi Fisis}

Fungsi fisis merupakan fungsi pemasaran yang meliputi atas fungsi pengangkutan, pengemasan, penyimpanan, pergudangan, serta pemrosesan untuk peningkatan nilai ekonomis barang yang dipasarkan.

Tabel 3. Tingkat Capaian Peran Pengelola Pasar Lelang atas Fungsi Fisis

\begin{tabular}{|c|c|c|c|c|}
\hline No. & Indikator & $\begin{array}{l}\text { Interval } \\
\text { Skor }\end{array}$ & $\begin{array}{l}\text { Capaian } \\
\text { Skor }\end{array}$ & $\begin{array}{c}\text { Tingkat } \\
\text { Capaian }(\%) \\
\end{array}$ \\
\hline \multicolumn{5}{|c|}{ Fungsi Pengangkutan } \\
\hline 1. & Membantu mengangkut cabai petani dari lahan ke pasar lelang & $0-3$ & 1,14 & 38 \\
\hline 2. & Meminjamkan sarana pengangkutan kepada petani & $0-2$ & 0,76 & 38 \\
\hline 3. & $\begin{array}{l}\text { Mengangkut cabai yang telah terjual kepada pemenang lelang } \\
\text { (menaikkan cabai ke mobil dll) }\end{array}$ & $0-2$ & 1,08 & 54 \\
\hline 4. & $\begin{array}{l}\text { Menyediakan tempat penyimpanan sementara untuk menyimpan } \\
\text { cabai petani sebelum dilelang. }\end{array}$ & $0-2$ & 1,40 & 70 \\
\hline 5. & Menyediakan tenaga pengangkutan untuk membantu petani & $0-2$ & 0,83 & 41 \\
\hline 6. & $\begin{array}{l}\text { Menyediakan tenaga pengangkutan untuk membantu pemenang } \\
\text { lelang }\end{array}$ & $0-2$ & 1,15 & 58 \\
\hline \multicolumn{2}{|r|}{ Jumlah atas Fungsi Pengangkutan } & 13 & 6,36 & 48,92 \\
\hline \multicolumn{5}{|c|}{ Fungsi Pengemasan } \\
\hline 7. & Memberikan layanan pengemasan cabai pemenang lelang & $0-2$ & 1,08 & 54 \\
\hline 8. & Menyediakan wadah/pengemas cabai & $0-3$ & 0,47 & 16 \\
\hline 9. & Mengemas cabai sesuai keinginan pemenang lelang & $0-2$ & 1,04 & 52 \\
\hline 10. & Menyediakan tenaga pengemas & $0-2$ & 1,10 & 55 \\
\hline \multicolumn{2}{|c|}{ Jumlah Atas fungsi pengemasan } & 9 & 3,69 & 41 \\
\hline \multicolumn{5}{|c|}{ Fungsi penyimpanan dan Pemrosesan } \\
\hline 11. & $\begin{array}{l}\text { Menyediakan gudang penyimpanan untuk menyimpan barang- } \\
\text { barang keperluan pasar lelang }\end{array}$ & $0-2$ & 1,30 & 65 \\
\hline 12. & Mengeringkan/mengangin-anginkan cabai apabila basah & $0-2$ & 1,31 & 66 \\
\hline 13. & Mengolah produk cabai menjadi produk bernilai tambah & $0-2$ & 0,15 & 8 \\
\hline 14. & Memanfaatkan cabai sortiran & $0-2$ & 0,61 & 30 \\
\hline \multicolumn{2}{|c|}{ Jumlah atas fungsi penyimpanan \& pemrosesan } & 8 & 3,37 & 42,13 \\
\hline & Jumlah keseluruhan & 30 & 13.42 & 44.73 \\
\hline
\end{tabular}

Sumber: Analisis data primer, 2014 
Dalam peran fisis ini pasar lelang menjalankan fungsinya berkaitan dengan pengangkutan sampai dengan peningkatan nilai ekonomis dari cabai yang akan dipasarkan. Berdasarkan Tabel 3, secara keseluruhan peran yang dilakukan oleh pengelola pasar lelang hanya mencapai $44,73 \%$. Faktor yang menyebabkan fungsi pengangkutan dinilai rendah oleh petani antara lain karena pengelola pasar lelang tidak menyediakan layanan untuk membantu mengangkut cabai petani dari lahan ke pasar lelang maupun menyediakan sarana pengangkutan yang dimiliki kelompok kepada petani. Sedangkan pada fungsi pemrosesan pengelola pasar lelang hanya menjualkan cabai dalam bentuk segar saja (tidak melakukan pengolahan lebih lanjut).

Berdasarkan Tabel 4, peran pengelola pasar lelang atas fungsi fisis paling banyak dinilai oleh petani berada pada kategori sedang $(61,18 \%)$. Sejatinya para petani mengharapkan peran pada fungsi fisis diberikan oleh pengelola pasar lelang dengan maksimal, namun para petanipun pada akhirnya memahami dan menerima keterbatasan pengelola pasar lelang dalam memenuhi peran fisis ini.

Tabel 4. Distribusi Kategori Peran Pengelola Pasar Lelang atas Fungsi Fisis

\begin{tabular}{|c|c|c|c|}
\hline \multicolumn{2}{|c|}{$\begin{array}{c}\text { Kategori } \\
\text { (skor) }\end{array}$} & $\begin{array}{l}\text { Jumlah } \\
\text { (orang) }\end{array}$ & $\begin{array}{c}\text { Persentase } \\
(\%)\end{array}$ \\
\hline Rendah & $0-10$ & 15 & 17,65 \\
\hline Sedang & $11-20$ & 52 & 61,18 \\
\hline Tinggi & $21-30$ & 18 & 21,18 \\
\hline \multicolumn{2}{|c|}{ Jumlah } & 85 & 100 \\
\hline
\end{tabular}

Sumber: Analsis data primer, 2014

Peran Pengelola Pasar Lelang atas Fungsi Penyediaan Sarana Prasarana

Tabel 5. Tingkat Capaian Peran Pengelola Pasar Lelang atas Fungsi Penyediaan Sarana

\begin{tabular}{|c|c|c|c|}
\hline Indikator & $\begin{array}{c}\text { Interval } \\
\text { skor }\end{array}$ & $\begin{array}{l}\text { Capaian } \\
\text { Skor }\end{array}$ & $\begin{array}{c}\text { Tingkat } \\
\text { Capaian }(\%) \\
\end{array}$ \\
\hline \multicolumn{4}{|l|}{ Peran atas fungsi penyediaan sarana informasi: } \\
\hline 1. $\quad$ Memberikan informasi kisaran harga cabai & $0-2$ & 1,22 & 61 \\
\hline 2. Menampilkan nama-nama pedagang yang mengikuti proses lelang & $0-2$ & 1,58 & 79 \\
\hline $\begin{array}{l}\text { 3. Menampilkan informasi jumlah cabai dan varietas cabai yang akan } \\
\text { dilelang }\end{array}$ & $0-2$ & 1,53 & 77 \\
\hline 4. Mencatat nama-nama petani yang menjual cabainya di pasar lelang & $0-2$ & 1,55 & 78 \\
\hline 5. Aktif menyampaikan informasi apapun tentang pemasaran cabai & $0-3$ & 1,49 & 50 \\
\hline Jumlah Peran atas fungsi penyediaan informasi & 11 & 7,37 & 67 \\
\hline \multicolumn{4}{|l|}{ Fungsi Penyediaan Sarana Komunikasi dan Sarana Pengumpulan } \\
\hline 6. Menjalin komunikasi dengan calon pembeli (pedagang) & $0-3$ & 2,17 & 72 \\
\hline 7. Menyediakan tempat untuk mengumpulkan cabai petani & $0-2$ & 1,56 & 78 \\
\hline Jumlah atas fungsi sarana komunikasi, pengumpulan & 5 & 3,73 & 74,6 \\
\hline \multicolumn{4}{|l|}{ Fungsi penanggungan resiko } \\
\hline $\begin{array}{l}\text { 8. Mengakomodir komplain dari pemenang lelang jika cabai yang } \\
\text { diperoleh memiliki cacat }\end{array}$ & $0-2$ & 1,22 & 61 \\
\hline $\begin{array}{l}\text { 9. Mengganti kerugian kepada pemenang lelang apabila ada komplain } \\
\text { cabai yang cacat }\end{array}$ & $0-2$ & 0,88 & 44 \\
\hline $\begin{array}{l}\text { 10. Menyampaikan kepada petani apabila ada komplain atas kualitas } \\
\text { cabai dari pemenang lelang }\end{array}$ & $0-2$ & 1,02 & 51 \\
\hline $\begin{array}{l}\text { 11. Menerapkan aturan standarisasi produk cabai yang akan dijual di } \\
\text { pasar lelang }\end{array}$ & $0-2$ & 1,32 & 66 \\
\hline Jumlah fungsi atas penanggungan resiko & 8 & 4,44 & 55,50 \\
\hline \multicolumn{4}{|l|}{ Fungsi grading dan penyortiran } \\
\hline 12. Melakukan grading pada semua cabai yang disetorkan petani & $0-2$ & 1,58 & 79 \\
\hline Jumlah fungsi atas grading dan penyortiran & 2 & 1,58 & 79 \\
\hline \multicolumn{4}{|l|}{ Fungsi Pembiayaan } \\
\hline $\begin{array}{l}\text { 13. Menalangi pembayaran cabai kepada petani jika pemenang lelang } \\
\text { membayar dengan tempo (tidak cash) }\end{array}$ & $0-3$ & 1,20 & 40 \\
\hline 14. Memotong harga jual cabai petani untuk operasional pasar lelang & $0-2$ & 1,60 & 80 \\
\hline Jumlah atas fungsi pembiayaan & 5 & 2,80 & 56 \\
\hline Jumlah Keseluruhan & 31 & 19,92 & 64,26 \\
\hline
\end{tabular}

Sumber: Analisis data primer, 2014 
Peran atas fungsi penyediaan sarana dan prasarana meliputi atas fungsi penyediaan sarana informasi pasar, fasilitasi komunikasi, pengumpulan, penanggungan resiko, standarisasi dan penyortiran, serta pembiayaan. Pemenuhan atas fungsi penyediaan sarana prasarana bertujuan agar kegiatan pemasaran maupun proses jual-beli cabai di pasar lelang bisa berjalan dengan lancar.

Berdasarkan Tabel 5, peran atas fungsi penyediaan sarana prasarana mencapai $64,26 \%$. Fungsi pembiayaan merupakan fungsi penyediaan sarana prasarana yang memiliki nilai khusus. Seringkali fungsi pembiayaan ini yang dianggap mewakili dari sekian banyak fungsi penyediaan sarana yang lain. Salah satu kekurangan dari pasar lelang yang menjadi catatan petani adalah sistem pembayarannya yang tidak bisa cash atau harus menunggu sampai 3 hari. Hal ini diperkuat oleh pendapat Bapak Mursyid (Garongan 3):

\section{"Ya kalau saya butuh uang segera ya terpaksa saya menjual cabai langsung ke pengepul, kalau ke pasar lelang kan harus nunggu 3 hari kadang ada yang 5 hari"}

Namun demikian jika petani memang sangat memerlukan uang yang mendesak, pengelola pasar lelang akan memberikan layanan kemudahan yaitu memberikan penalangan terlebih dahulu. Hal ini yang seringkali membuat petani merasa gengsi untuk meminta talangan pembayaran kepada pengelola pasar lelang dan memilih menjual sebagian kecil hasil panennya ke pedagang tengkulak. Hal ini seperti yang disampaikan oleh Bapak Karman (Pengelola Lelang Bugel 1):

"Ya kita juga memahami kalau petani adakalanya butuh uang untuk pupuk, petik, keperluan anak sekolah maupun keperluan mendesak lainnya, nah sebenarnya kami juga bisa menalangi dulu keperluan yang dibawah 1 jutaan namun ya itu harus disampaikan ke pengelola agar kami tahu"

Apabila fungsi pembiayaan yaitu menalangi pembayaran $(40 \%)$ dibandingkan dengan fungsi penyediaan lainnya secara keseluruhan (mencapai 67\%) maka fungsi pembiayaan tidak bisa dikatakan secara signifikan mampu mewakili fungsi penyediaan sarana. Namun seringkali fungsi pembiayaan menutup fungsi penyediaan sarana yang lain sehingga salah satu kekurangan pasar lelang ini dianggap sangat menonjol.

Tabel 6. Distribusi Kategori Peran Pengelola Pasar Lelang atas Fungsi Penyediaan Sarana

\begin{tabular}{lccc}
\hline & $\begin{array}{c}\text { Kategori } \\
\text { (skor) }\end{array}$ & $\begin{array}{c}\text { Jumlah } \\
\text { (orang) }\end{array}$ & $\begin{array}{c}\text { Persentase } \\
(\%)\end{array}$ \\
\hline Rendah & $0-10,33$ & 0 & 0 \\
Sedang & $10,34-20,67$ & 19 & 22,35 \\
Tinggi & $20,68-31$ & 66 & 77,65 \\
\hline & Jumlah & 85 & 100 \\
\hline
\end{tabular}

Sumber: Analisis data primer, 2014

Berdasarkan Tabel 6 tersebut, justru diperoleh data bahwa peran atas fungsi penyediaan sarana yang dilakukan oleh pengelola pasar lelang dinilai oleh 66 petani berada pada kategori tinggi $(77,65 \%)$, sedangkan sebanyak 19 orang $(22,35 \%)$ sisanya menilai pada kategori sedang. Peran pengelola pasar lelang atas fungsi penyediaan sarana akan mempengaruhi perilaku petani dalam memasarkan cabainya di pasar lelang, hal ini seperti dalam kasus ketika fungsi penalangan hasil penjualan (fungsi pembiayaan) tidak berjalan baik maka petani akan mengalihkan pemasarannya ke saluran pemasaran yang lain sekalipun tanpa meninggalkan pemasaran di pasar lelang sepenuhnya. Atau dengan kata lain petani tetap menggunakan pasar lelang namun di sisi lain pada kondisi terdesak perlu uang segera maka petani juga menjual cabainya ke pedagang pengepul. Hal ini diperkuat oleh pendapat Misdi (Garongan 3).

\section{"Ya saya akan menjual ke bakul pengepul kalau sangat terdesak keperluan, tapi paling kan ya tidak banyak, paling-paling jual sekitar $25 \mathrm{~kg}$. masak mau nagih ke pasar lelang, ya mending menjual sedikit tapi terpenuhi lah, gampang juga kan"}

Pemasaran cabai melalui pasar lelang merupakan salah satu bentuk interaksi sosial bermuatan ekonomi. Teori pertukaran sosial menurut Basrowi dan Soenyono (2004) menyatakan bahwa hubungan sosial memiliki unsur ganjaran, pengorbanan, dan keuntungan yang saling mempengaruhi. Ganjaran merupakan segala hal yang diperoleh melalui adanya pengorbanan. Keuntungan merupakan selisih antara keuntungan dengan pengorbanan. Prinsipnya jika dalam suatu perilaku tertentu 
memberikan keuntungan, maka perilaku itu akan senantiasa diulang dan dilakukan secara terus menerus oleh seseorang, termasuk dalam hal ini jika perilaku dalam pasar lelang menguntungkan maka akan senantiasa dilakukan oleh petani.

Pemasaran cabai sebagai suatu bentuk interaksi sosial bermotif ekonomi mengandung interaksi pertukaran antar kedua pihak (resiprosisten antara petani dengan pedagang). Dalam interaksi sosial ini terdapat unsur ganjaran, pengorbanan, dan keuntungan yang saling mempengaruhi ketiga pihak (petani, pengelola pasar lelang, dan pedagang tengkulak) untuk menilai apakah pertukaran yang dilakukan menguntungkan atau merugikan.

Ganjaran bagi petani bisa dimaknai sebagai sesuatu hal yang menarik yang membuat petani akan menjual cabainya lagi di pasar lelang. Apabila menjual cabai di pasar lelang merupakan suatu hal yang menguntungkan, maka pada panen-panen ke depannya bisa dipastikan petani akan menjual cabainya di pasar lelang lagi. Berdasarkan kajian yang telah diuraikan di depan, ganjaran yang diperoleh petani melalui pasar lelang ini berwujud; (1) harga jual yang lebih tinggi dibandingkan dengan saluran pemasaran yang lain, serta (2) layanan kemudahan penjualan yang diterima petani melalui peran dari pengelola pasar lelang. Dua hal ini dipastikan menjadi faktor yang menyebabkan petani mengulang penjualannya melalui pasar lelang. Selain dua faktor tersebut petani juga takut terkena punishment apabila menjual cabainya di luar pasar lelang, mengingat komitmen kelompok tani membentuk pasar lelang adalah untuk memberikan kemudahan kepada anggotaanggotanya untuk memasarkan cabainya.

Meskipun pasar lelang menghadirkan dua ganjaran bagi petani, namun petani juga dituntut untuk memberikan dua pengorbanan, yaitu: (1) sistem pembayaran yang tidak cash, serta (2) petani harus melakukan grading dan sortasi atas cabai yang akan dikumpulkan. Dua pengorbanan ini merupakan hal yang tidak perlu dilakukan petani apabila mereka menjual cabainya secara langsung kepada pedagang pengepul. Sekalipun pembayaran tidak cash namun petani memiliki trust bahwa mereka akan tetap memperoleh harga yang sesuai dengan lelang. Kepercayaan inipun telah dijamin dalam aturan bahwa pembayaran lelang paling lama akan dilakukan 3-5 hari setelah proses lelang.
Kepercayaan petani kepada pengelola pasar lelang bukan semata berkaitan dengan masalah pembayaran namun juga berkaitan dengan posisi pengelola pasar lelang. Pengelola pasar lelang sebagai agen (bukan broker) nampak bahwa pengelola pasar lelang tidak mengambil keuntungan atas jasa penjualan cabai tersebut. Potongan harga dari harga yang diperoleh petani salah satunya digunakan untuk gaji pengelola, dimana gaji pengelola besarannya masih sangat wajar, bahkan terkadang pengelola terhitung lebih banyak berkorban. Transparansi harga ini bisa dibuktikan secara nyata bahwa selisih harga jual yang diterima petani dengan harga dalam lelang tidak jauh berbeda. Artinya uang yang diterima petani benar-benar hanya dipotong sesuai dengan potongan yang telah disepakati perhitungannya.

Keuntungan harga tinggi dan kemudahan penjualan dinilai petani masih lebih menguntungkan daripada pengorbanan yang harus mereka lakukan. Selisih antara pengorbanan dengan ganjaran inilah yang menghasilkan keuntungan bagi petani cabai lahan pasir pantai di Kecamatan Panjatan, Kulon Progo yang membuat mereka masih setia untuk memasarkan cabainya melalui pasar lelang. Interaksi bermuatan ekonomi yang menguntungkan ketiga belah pihak inilah yang akan melanggengkan keberadaan pasar lelang sebagai lembaga ekonomi pertanian.

Peran menurut Kozier (1995) dalam Suyatno (2011) diartikan sebagai seperangkat tingkah laku yang diharapkan oleh orang lain terhadap seseorang sesuai kedudukannya dalam sistem. Peran juga merupakan bentuk dari perilaku yang diharapkan dari seseorang pada situasi sosial tertentu. Rogers dan Shoemaker (1986) menyatakan bahwa perilaku merupakan tindakan yang nyata yang dapat dilihat dan diamati sebagai suatu akibat terjadinya pengetahuan atau stimulus. Perilaku petani dalam pasar lelang bisa dipengaruhi oleh peran pengelola pasar lelang atas fungsi pemasaran. Kotler (1995) dalam Firdaus (2008) menyebutkan bahwa pemasaran adalah suatu proses sosial dan manajerial dimana individu dan kelompok mendapatkan kebutuhan dan keinginan mereka dengan menciptakan, menawarkan dan bertukar sesuatu yang bernilai sama atau lain.

Firdaus (2008) menjabarkan fungsi-fungsi pemasaran menjadi tiga golongan berikut:

a. Fungsi pertukaran (exchange function), yang terdiri atas fungsi penjualan dan pembelian. Fungsi ini akan menciptakan kegunaan hak 
milik yang di dalamnya terdiri dari aktifitas layanan perencanaan produk, mencari kontak penjual dan pembeli, menciptakan permintaan, negosiasi serta kontrak jual beli.

b. Fungsi fisis (physical function) yang meliputi fungsi pengangkutan, bongkar muat, dan pergudangan. Fungsi ini menciptakan kegunaan tempat dan waktu

c. Fungsi penyediaan sarana (facilitating function), yang meliputi kegiatan standarisasi dan grading, penanggungan resiko, pembiayaan, kredit, informasi pasar dan harga. Fungsi pelancar akan menciptakan kegunaan bentuk.

Pasar lelang yang mampu berperan dalam 3 fungsi pemasaran tersebut akan senantiasa dipilih oleh petani untuk memasarkan cabainya, dengan alasan memasarkan cabai melalui pasar lelang dinilai lebih efektif jika dibandingkan dengan petani harus memasarkan cabainya sendiri. Selain itu memasarkan cabai melalui pasar lelang memberikan banyak keuntungan dan kemudahan bagi para petani.

\section{KESIMPULAN}

Pasar lelang merupakan lembaga pemasaran berbentuk agen yang dibentuk oleh kelompok tani untuk memasarkan hasil cabai petani secara berkelompok. Keberadaan pasar lelang menggantikan posisi petani untuk melakukan fungsi pemasaran seperti fungsi pertukaran, fungsi fisis serta fungsi penyediaan sarana pasar sehingga fungsi ini tidak perlu dilakukan sendiri oleh petani. Pada posisi ini petani sudah diuntungkan secara tenaga, waktu dan materi. Selain itu model pemasaran secara berkelompok akan mampu meningkatkan posisi tawar petani dalam proses negosiasi harga, terlebih dalam pasar lelang penentuan harga dilakukan melalui lelang tertutup berdasarkan harga tertinggi. Hal inilah yang menyebabkan harga jual cabai di pasar lelang lebih tinggi dibandingkan dijual langsung oleh petani kepada pedagang pengepul. Efisiensi atas fungsi pemasaran serta harga jual yang lebih tinggi inilah yang menyebabkan petani lebih memilih menggunakan pasar lelang untuk memasarkan hasil cabainya.

Peran pengelola pasar lelang yang terdiri atas fungsi pertukaran dan fungsi penyediaan sarana memberikan kemudahan petani untuk memasarkan cabainya melalui pasar lelang. Layanan fungsi pemasaran yang diberikan oleh pengelola pasar lelang tersebut dinilai lebih efektif jika dibandingkan dengan dilakukan sendiri oleh petani sehingga petani tidak perlu melakukan fungsi pemasaran sendiri. Semakin banyak layanan pemasaran yang difasilitasi oleh pengelola pasar lelang maka akan semakin mempengaruhi perilaku petani cabai untuk memasarkan cabainya di pasar lelang.

\section{DAFTAR PUSTAKA}

Basrowi, M., \& Soenyono. 2004. Teori Sosial dalam Tiga Paradigma. Surabaya: V. de Press.

Firdaus, M. 2008. Manajemen Agribisnis. Jakarta: Bumi Aksara.

Kuntadi, E.B. 2011. Efisiensi Pemasaran Cabai Merah Lahan Pasir Pantai Melalui Pasar Lelang di Daerah Istimewa Yogyakarta (Tesis S-2). Universitas Gadjah Mada, Yogyakarta. Tidak dipublikasikan.

Mardjoko, T. 2004. Pasar Lelang Harapan Baru Memperbaiki Posisi Tawar Petani. Online: www.bappebti.go.id.

Mulyadi. 1991. Akuntansi Biaya. Yogyakarta: Aditya Media.

Pusat Penyuluhan Pertanian, Badan Penyuluhan dan Pengembangan SDM Kementerian Pertanian. 2012. Petunjuk Pelaksanaan Pengembangan Kelembagaan Ekonomi Petani.

Rogers, E.M., \& Shoemaker, F.F. 1986. Communication of Innovations: A Cross Cultural Approach. London: Collier MacMill Publisher.

Suyatno. 2011. Optimalisasi Peran Kodim dalam Pembinaan Pemuda Partai dalam Rangka Penyiapan Sumber Daya Pertahanan Negara: Studi Kasus di Kodim 0503/713 Wilayah Jakarta Barat (Tesis S2). Universitas Gadjah Mada, Yogyakarta. 